\title{
Dinamika Politik, Heroifikasi Kim Il Sung, dan Ideologi Juche di Korea Utara (1948-2011)
}

\author{
Nur Fatah Abidin \\ nurfatah@staff.uns.ac.id \\ Universitas Sebelas Maret Surakarta
}

\begin{abstract}
Historical analysis of the North Korea becomes essential nowadays due to the increase of nuclear and global politic issues. This research analyzes the political history of North Korea, especially in the term of political strategy from 1948 to 2011, that has been used by Kim Dynasty to hold their political power for over eight decades. The research method was a literature review of the history of North Korea. The findings of the research show that the political dynasty in North Korea operates preventive and repressive strategies in form of Juche ideology. Juche ideology can be seen as the acculturation of the spirit of communism and local values along with the de-Stalinization process (1956) in North Korea. The improvement of bureaucracy and military power is part of mass control. Meanwhile, the use of terror can be seen as a way to diminish political opposition. By using those strategies, the Kim Dynasty can manage and hold their power as well as get loyalties from the people.
\end{abstract}

Keywords: North Korea, Kim Il Sung, Juche Ideology, History of East Asia

\begin{abstract}
Abstrak
Kajian sejarah Korea Utara menjadi penting dewasa ini sejalan dengan peningkatan isu nuklir dan politik global. Penelitian ini bertujuan untuk mengungkap dinamika sejarah politik Korea Utara, khususnya terkait strategi politik Korea Utara tahun 1948 sampai 2011, yang digunakan oleh dinasti Kim untuk mempertahankan kekuasaan politiknya selama hampir delapan puluh tahun. Metode penelitian adalah kajian pustaka terkait sejarah Korea Utara. Temuan penelitian menunjukkan bahwa dinasti politik di Korea Utara menyusun strategi preventif dan represif dalam bentuk ideologi negara yaitu ideologi Juche. Ideologi Juche merupakan akulturasi dari semangat komunis dan budaya setempat yang berkembang sejalan dengan proses de-Stalinisasi (1956) di Korea Utara. Penguatan birokrasi dan militer yang loyal diupayakan sebagai alat pengendali masa. Penggunaan teror juga diterapkan sebagai bentuk langkah represi terhadap para oposan dalam negeri. Melalui strategi politik tersebut, dinasti Kim dapat bertahan dari tantangan politik internal dan mendapatkan loyalitas rakyat secara berkesinambungan.
\end{abstract}

Kata Kunci: Korea Utara, Kim Il Sung, Ideologi Juche, Sejarah Asia Timur 
Nur Fatah Abidin

Dinamika Politik, Heroifikasi Kim Il Sung, dan Ideologi Juche di Korea Utara (1948-2011)

\section{Pendahuluan}

Kajian mengenai sejarah Korea Utara menjadi semakin penting untuk ditelaah sejalan dengan peningkatan ketegangan antara Korea Utara dan Amerika Serikat pada dekade kedua abad 21. Dalam pandangan Amerika Serikat, permasalahan nuklir dan keamanan global menjadi isu yang melekat dalam permasalahan Korea Utara (Pollack, 2017). Meskipun demikian, permasalahan Korea Utara belum dapat dijelaskan memadai. S. Choi (2014) dan Pardo (2019) bahkan menyatakan bahwa permasalahan Korea Utara sebagai fiksi karena ketiadaan kajian akademik secara berimbang antara kedua pihak. Akibatnya, citra Korea Utara hanya dipandang dari satu sisi. Sebagai warga negara dunia, masyarakat Indonesia memerlukan penjelasan yang memadai mengenai dinamika politik internal Korea Utara yang memengaruhi kebijakan politik luar negerinya. Secara historis, Indonesia memiliki hubungan diplomatic yang cukup erat dengan Korea Utara, khususnya masa pemerintahan Presiden Soekarno pada tahun 1960-an. Hubungan ini menunjukkan akar historis dari hubungan Indonesia dan Korea Utara beserta dinamika global yang menyertainya. Sejarah menunjukkan bahwa hubungan Indonesia dan Korea Utara mengalami pasang surut sejalan dengan dinamika global dan internal dari masing-masing negara (Mason, 2020; Mobrand \& Kim, 2019). Dengan memahami dinamika politik internal, dasar-dasar politik luar negeri Korea Utara dapat dipahami dalam kerangka yang menyeluruh meliputi motif dan psikologis dari masyarakatnya. Oleh karena itu, kajian historis korea utara ini menjadi penting untuk dipaparkan secara lebih lanjut.

Korea Utara merupakan negara yang berada di wilayah Semenanjung Korea. Rentang geografis Korea Utara didominasi oleh pegunungan dan perbukitan. Wilayah subur Korea Utara hanya mencakup 17.3 persen atau sekitar 21,173 kilometer persegi. Pegunungan Changbaek dengan Gunung Paektu sebagai puncak tertinggi (2,750 meter) berada di sisi utara Korea Utara (So \& Duarte, 2020). Gunung Paektu menempati kedudukan penting dalam memori kolektif masyarakat Korea Utara sebagai Gunung Suci tempat pemimpin Korea Utara dilahirkan (E. K. Choi et al., 2003). Pusat aktivitas politik dan ekonomi berada di Pyongyang, Ibu kota Korea Utara. Di samping itu, Korea Utara juga memiliki kota-kota besar yaitu Hamnung, Chongjin, Wonsan, Nampo, Kaesong, Kaesung, Haeju dan Rajin-Sonbong. Sekitar tujuh puluh tujuh persen dari kota-kota tersebut berada di wilayah pegunungan tinggi yang dipisahkan oleh lembah dan perkebunan. Aktivitas perekonomian Korea Utara secara garis besar dibedakan menjadi dua, yaitu daerah utara dengan kemajuan industri akibat simpanan sumber daya alam mineral dan wilayah selatan yang didominasi oleh sektor agrikultural (Lim, 2008; Winstanley-Chesters, 2020). Total populasi Korea Utara sekitar 25 juta ketika negara tersebut merdeka dari Jepang pada tahun 1945. Pada tahun 1998, populasi Korea Utara adalah sekitar 23.56. Konfigurasi masyarakat Korea Utara bersifat homogen. 
Kelompok-kelompok masyarakat menggunakan bahasa yang sama. Komposisi etnis di Korea Utara meliputi etnis Korea, China dan Jepang. Agama yang dianut adalah Budhism, Shamanism, Chondogyo dan Kristen, akan tetapi praktik-praktik keagamaan tersebut hampir tidak dilaksanakan sejak tahun 1948 (E. K. Choi et al., 2003).

Sejara Korea Utara dapat ditelusuri hingga masa kerajaan-kerajaan kuno. Korea Utara pada awalnya merupakan bagian dari kerajaan Choson yang didirikan oleh Tangun pada tahun 2333 B.C. Pada 57 SM - 668 M terbentuk tiga kerajaan di wilayah Korea yaitu Koguryo di Manchuria, Paekche dan Shilla. Dalam perkembangan selanjutnya ketiga kerajaan tersebut ditaklukkan oleh Shilla yang kemudian menyatukan seluruh kerajaan smpai dengan 918 M. Kerajaan Shilla kemudian digulingkan oleh Wang Kon, yang kemudian mendirikan Kerajaan Koryo - dalam bahasa Inggris kemudian dilafalkan sebagai Korea - yang eksis sampai dengan tahun 1392 ketika pada akhirnya Jenderal Yi Song-Gye melakukan kudeta dan mendirikan Dinasti Yi yang dikenal oleh sejarawan sebagai Dinasti Choson. Modernisasi di Korea mulai terjadi pada tahun 1876 ketika Kerajaan Choson dipaksa untuk membuka Korea. Dinasi Choson berakhir pada tahun 1910 ketika Jepang menduduki Korea sampai dengan akhir Perang Dunia II (1945). Pada akhir perang Dunia II, korea muncul sebagai negara yang merdeka, akan tetapi permasalahan lain yaitu disintegrasi mulai berkembang di wilayah Korea. Penyebabnya tidak lain adalah keberadaan Amerika Serikat (AS) dan Uni Soviet (USSR) yang kemudian membagi garis demarkasi pada $38^{\circ}$ sesuai dengan garis penyerahan pendudukan Jepang. Meskipun pada awalnya garis tersebut bersifat sementara, tetapi pada akhirnya menjadi garis permanen yang memisahkan antara Korea Utara dan Korea Selatan (E. K. Choi et al., 2003).

Pemerintahan baru di Korea Utara tersebut dipimpin oleh Kim Il Sung (1948). Pada dasarnya dapat dikatakan bahwa Sejarah awal Korea Utara adalah sejarah perjuangan Kim Il Sung untuk mencapai kemerdekaan. Kim Il Sung merupakan pendiri dan pemimpin Korea Utara selama kurang lebih 50 tahun. Kim Il Sung merupakan tokoh yang bergerak di luar Korea Utara selama masa pendudukan Jepang. Setelah menyelesaikan pendidikannya di Sekolah Menengah Yukmun, Kim Il Sung kemudian bergabung dengan Pasukan Anti Jepang yang berperang melawan Jepang di wilayah Korea dan Manchuria. Kondisi tersebut mengakibatkan dirinya tidak memiliki basis politik yang kuat di Korea Utara menjelang akhir pendudukan Jepang. Kesuksesannya dalam meraih tampuk kepemimpinan di Korea Utara semata-mata atas prakarsa USSR yang menempatkan Kim Il Sung sebagai kepala pemerintahan dan kepala Partai Komunis Korea Utara. Sementara itu, para veteran yang berperang bersama Kim Il Sung kemudian pada akhirnya akan menempati posisi penting dan kuat dalam birokrasi pemerintahan korea Utara. Kelompok tersebut kemudian disebut sebagai faksi 
manchurian. Secara keseluruhan, Kim Il Sung dapat dikatakan sebagai pembentuk dasar-dasar bangunan rezim komunis ataupun rezim pemerintahan keluarganya di Korea Utara. Pada masa pemerintahan Kim Il Sung terjadi beberapa peristiwa besar yang memengaruhi pemerintahan Korea Utara, misalnya saja proyek de-stalinisasi (1956) yang mengakibatkan Korea Utara merubah ideologi negara yang sesuai dengan kondisi sosial dan kebudayaannya (Lim, 2008). De-stalinisasi adalah program yang lebih mengedepankan aspek humanism dari model sosialisme Leninisme dan membawa perubahan besar bagi negara dalam blok komunis. Dampak dari proyek de-stalinisasi juga menyentuh Korea Utara dan akan dianalisis lebih mendalam pada bagian hasil dan pembahasan dalam tulisan ini.

Sepeninggal Kim Il Sung, tampuk kepemimpinan di Korea Utara diwariskan kepada Kim Jong Il yang merupakan anak dari Kim Il Sung. Kim Jong Il ditetapkan sebagai pengganti Kim Il Sung pada tahun 1994. Karir politik Kim Jong Il dimulai pasca menyelesaikan sekolah di Universitas Kim Il Sung, Kim Jong Il kemudian ditempatkan di Departemen Organisasi Partai Pekerja Korea. Posisinya semakin meningkat tatkala ditunjuk sebagai wakil dalam Komite Politburo pada tahun 1980. Kebijakan ekonomi, politik dan diplomasi yang dilaksanakan Kim Jong Il berbeda dengan kebijakan masa Kim Il Sung. Kebijakan Kim Jong Il dapat disebut sebagai kebijakan yang bersifat lebih terbuka. Hal tersebut ditunjukkan dengan aktivitas diplomatik dengan negara-negara lain yang terjadi pada masa pemerintahan Kim Jong Il dari tahun 1994 sampai dengan 2011. Ketika Kim Jong Il menginggal dunia pada tahun 2011 (O Hanlon \& Mochizuki, 2004). Kim Jong Un yang merupakan putra dari Kim Jong Il kemudian diangkat sebagai pemimpin Korea Utara yang baru. Rezim pemerintahan Kim Jong Un berkuasa hingga hari ini di Korea Utara. Daya tahan dinasti Kim di Korea Utara menjadi bagian penting dalam dinamika politik internal Korea Utara. Penelitian ini bertujuan untuk mengkaji strategi politik yang dinasti Kim Jong Un untuk mempertahankan kekuasaannya di Korea Utara.

\section{Metode}

Penelitian ini menggunakan metode riset pustaka yang disusun oleh Zed (2004). Menurut Zed (2004) terdapat 7 langkah dalam melakukan riset pustaka yaitu: (1) pemilihan ide umum topik penelitian, (2) pencarian informasi pendukung, (3) penguatan fokus dan organisasi bahan bacaan, (4) pencarian dan penemuan bahanbahan Pustaka, (5) pengorganisasian bahan Pustaka, (6) pengkajian bahan pustaka, dan (7) reorganisasi catatan Pustaka. Beberapa Pustaka yang ditelaah dalam penelitian ini terdiri dari pustaka mengenai dinamika sejarah Korea Utara dan catatan-catatan perjalanan dari duta besar di Korea Utara yang telah dibukukan. Pustaka yang dikaji yaitu buku dan jurnal yang relevan terkait dinamika politik di Korea Utara. Selain itu, 
DIAKRONIKA 20 (1) 2020

ISSN: 1411-1764 (Print) | 2620-9446 (Online)

untuk memberikan gambaran alternatif, pustaka mengenai perjalanan masyarakat luar Korea, khususnya warga negara Amerika dan Eropa misalnya catatan Eddie Burdick (2014) berjudul Three Days in the Hermit Kingdom: An American Visits North Korea dan catatan Erik (2005) berjudul North Korea Under Communism: report of an Envoy to Paradise juga menjadi bagian dari pustaka yang dikaji. Berdasarkan kajian Pustaka tersebut, peneliti menyusun kajian historis mengenai strategi politik Korea Utara, khususnya dinasti Kim, mulai dari era pembentukan negara Korea Utara sampai dengan akhir kekuasaan Kim Jong Il (2011).

\section{Hasil dan Pembahasan}

Kebijakan dalam negeri Korea Utara dalam kaitannya dengan usaha mempertahankan keberlangsungan rezim politik dan loyalitas rakyat cenderung menggunakan kebijakan represif, strategi indoktrinasi, dan pembangunan mitos kepahlanwanan Kim Il Sung. Pada masa awal pendirian Korea Utara, konstelasi gerakan rakyat di Korea Utara pada awalnya dari tiga kekuatan yaitu nasionalis, sosialis dan mantan pemimpin korea yang berada di luar negeri khususnya di China dan USSR. Gerakan nasionalis berasal dari Russia dan Cina pada awal 1910 setelah pendudukan Jepang di Korea. Gerakan nasionalis tersebut menentang pendudukan Jepang dan bekerjasama dengan gerakan komunis China di Yenan. Gerakan nasionalis di Korea terebut mengorganisasi perlawanan untuk memerdekakan Korea. Pada akhir perang Dunia II, para kaum nasionalis Korea tersebut kemudian kembali ke Korea dan bergabung ke pemerintahan yang baru. Pada masa awal kemerdekaan, Kim Il sung berhasil memersatukan Korea Utara. Tiga kekuatan politik yaitu: (1) faksi Nasionalis yang dipimpin Cho Man-shik yang merupakan kelompok yang memiliki basis massa terbesar; (2) faksi Sosialis (Kelompok Chinese Yenan) yang dipimpin oleh Kim Tu-Bong yang terdiri dari kelompok intelektual dan merupakan kelompok yang bergabung dengan pasukan Mao Zedong di Yenan pada tahun 1930 sampai dengan 1940 serta; (3) faksi Manchurian yang bergabung dengan Kelompok Korea Pro-Soviet yang merupakan generasi kedua dari imigran korea di USSR. Ketiga faksi tersebut dengan keberagaman latar belakang dan garis manuver. Melalui penyatian tiga faksi politik tersebut, Kim Il Sung berhasil menyatukan kekuaasaanya dan mentasbihkan dirinya sebagai pemimpin utama di Korea Utara pada tahun 1948 (E. K. Choi et al., 2003).

Sementara itu, kebijakan politik dalam negeri dibangun atas dasar prinsip totalitarian state berbasis ideologi komunis. Kim Il Sung mendirikan KWP pada tahun 1945 dan menguasainya sampai setengah abad hingga dia meninggal pada tahun 1994. Struktur partai KWP menggunakan pola Partai Komunis Uni Soviet (CPSU) dengan kepemimpinan yang terpusat di tangan Kim Il Sung. Hanya sedikir dari komite partai 
KWP (CC Politbiro) yang memiliki kontrol dalam pemerintahan Korea Utara. Dalam KWP kongres partai dilaksanakan setiap empat tahun sekali, akan tetapi kongres partai tidak dilaksakana sejak dua dekade terakhir. Kongres partai terakhir merupakan kongres ke VI yang dilaksakanan pada bulan Oktober 1980. Kondisi yang hampir sama terjadi dalam struktur pemerintahan Korea Utara yang mengadopsi sistem pemerintahan Uni Soviet. Kim Il Sung memimpin Korea Utara selama lima dekade sebagai perdana menteri (1950-1960) kemudian sebagai Presiden setelah perubahan konstitusi pada tahun 1972. Kim Il Sung juga menjabat sebagai Chairman of The Administrative Council, pemimpin Central Poeples Comitte. Dengan demikian dapat dikatakan bahwa partai KWP menguasai pemerintahan dan birokrasi di Korea Utara. Meskipun demikian sistem pemerintahan tersebut juga tidak dapat dilepaskan dari struktur karakteristik yang dimiliki oleh masyarakat Korea khususnya praktik politik lokal masa Dinasti Choson (Mastro, 2020). Kim Il Sung memimpin Korea Utara seperti raja dari dinasti Chongson dan ideologi Juche mengadopsi pemikiran konfusianisme sama sepertihalnya pada masa pemerintahan Dinasti Choson (Lutz, 2015). Mekanisme politik di Korea Utara dijalankan melalui partai politik. Sistem pemerintahan Korea Utara dijalankan oleh satu partai dengan Partai Pekerja Korea - dalam bahasa Inggris disebut Korean Workers Party (KWP)- sebagai kekuatan utama Disamping itu terdapat dua partai lain yaitu Korean Social Democratic Party (KSDP) dan Partai Chondoist Chongu yang bersifat religius. Meskipun demikian, kedua partai tersebut tidak mampu untuk menyamai kekuatan KWP. Semua keputusan mengenai kebijakan pemerintahan seperti pegawai pemerintahan, kabinet, perdana mengeneti diputuskan oleh Komite Sentra KWP. Kedudukan sentral ada di tangan Komisi Pertahanan Nasional. KPN merupakan inti dari birokrasi pemerintahan Korea Utara. Lembaga negara dipisahkan kedalam tiga aspek: (1) Eksekutif yang dipimpin oleh Komisi Pertahanan Nasional; (2) Legislatif; serta (3) Yudisial (E. K. Choi et al., 2003).

\section{Ideologi Juche dan Kepahlawanan Kim Il Sung}

Untuk mengikat ketiga elemen politik di Korea Utara serta memperkuat legitimasi kekuasaannya, Kim Il Sung memutuskan untuk memodifikasi ideologi komunis ala USSR sesuai dengan karakteristik sosial, budaya dan sejarah Korea Utara. Ketika Korea Utara didirikan, ideologi yang dianut mengadopsi dari ajaran MarxismLeninism. Meskipun, pada tahun 1960-an ideologi tersebut kemudian diganti dengan ideologi Juche yang didasarkan pada penerapan Marxisme dan Leninisme dalam kehidupan masyarakat Korea Utara. Kim Il Sung memantapkan kebijakan berbasis pada ideologi juche dalam self identity dan self reliance selama tahun 1960an. Pada masa tersebut Korea Utara beradaptasi menjadi hermit nation dengan mengisolasi diri dari semua kontak dengan dunia luar dan maintained myopic, mengisolasi pandangan 
DIAKRONIKA 20 (1) 2020 ISSN: 1411-1764 (Print) | 2620-9446 (Online)

dunia merupakan hal yang cukup sulit untuk diterima oleh negara lain. Di sisilain pada tahun-tahun yang sama, Kim Il Sung meningkatkan serangan ke Korea Selatan dengan meningkatkan aktivitas Gerilyawan (Lim, 2008).

Perubahan tersebut disebabkan oleh terjadinya konflik ideologis. Pasca kematian Stalin pada tahun 1953, terjadi perubahan besar dalam tubuh USSR. Perubahan yang dilakukan oleh Nikita Khrushchev dengan melaksanakan program de-Stalinization. Program de-Stalinisasi merupakan program baru yang lebih mengedepankan aspek humanisme dari model sosialisme Leninisme pada tahun 1950. Dalam program tersebut Khrushchev mengkampanyekan perubahan yaaitu dalam hal partai harus memegang kontrol penuh dalam kebijakan domestik dan luar negeri. Perubahan tersebut membawa perubahan besar bagi negara-negara komunis lainnya, meskipun reaksi negara-negara tersebut beraneka ragam. Di beberapa negara, penguasa lokal memilih untuk mengikuti kebijakan USSR yang kemudian berkembang menjadi gerakan poststalinis. Sementara itu di Korea Utara, Rumania, China dan Albania, penguasa lokal menolak kebijakan USSR yang kemudian mengembangkan model stalinis tersendiri atau disebut juga sebagai independent stalinism (Lankov, 2007).

Proyek de-stalinisasi tersebut menyebabkan terjadinya peristiwa Agustus 1956. Peristiwa Agustus 1956 merupakan satu persitiwa penting dalam sejarah Korea Utara, akibat merebaknya de-salinisasi dari USSR dan kegagalan upaya gerakan oposisi untuk penggantian Kim Il Song di Korea Utara. Dalam kondisi tersebut Kim Il Sung berhasil bertahan dan justru mengarahkan Korea Utara ke arah kebijakan yang baru. Kondisi tersebut menandai berakhirnya struktur kekuasaan lama di Korea Utara dan pembentukan struktur baru. Kim Il Sung menunjukkan bahwa kekuasaannya bukan lagi merupakan boneka dari kekuasaan asing (E. K. Choi et al., 2003). Dampak dari peristiwa Agustus 1956 bagi kekuasaan Kim Il Sung adalah kemenangan personal dan rezim Kim Il Sung pada akhirnya berhasil bertahan. Kim Il Sung berhasil menumpas gerakan oposisi dalam pemerintahannya, menambah jumlah partisan dan merubah dasar negara dari Stalinisme menuju ideologi Juche (Ford \& Kwon, 2007).

Dalam kondisi tersebut Korea Utara memutuskan untuk mengambil jalan lain dengan memutuskan mandiri terlepas dari dukungan ekonomi China ataupun USSR dan meningkatkan kekuatan militer dengan loyalitas, dedikasi dan fanatisme yang tinggi terhadao negara mereka (E. K. Choi et al., 2003). Korea Utara mulai lepas dari bayang-bayang rezim USSR. Pidato-pidato pemimpin korea utara tidak lagi disortir oleh rezim USSR. Mekipun demikian bahasa Russia tetap menjadi bahasa asing utama di Korea Utara, Film, makanan serta hiburan berbau Russia juga tetap ada (Lankov, 2007). 
Ideologi Juche merupakan suatu ideologi yang dicetuskan Kim Il Sung dan dijadikan legitimasi kekuasaan serta landasan filosofis pelaksanaan negara oleh Kim Jong Il. Juche ideologi terdiri dari dua bagian yaitu: (1) teori filosofis dengan prinsip “Revolutionery View of The Leader yang menekankan bahwa masa tidak akan pernah mampu melaksanakan revolusi tanpa adanya pasukan revolusi yang dipimpin oleh seorang suryong. Landasan tersebut juga menyatakan bahwa Kim Jong Il sebagai suryong (leader). Landasan tersebut juga digunakan Kim Il Jung sebagai legitimasi dirinya untuk menggantikan peran ayahnya. Teori tersebut diperkuat pada tahun 1980 dengan keluarnya "Theory of The Immortal Socio-Political Body" yang menekankan pada tiga kekuatan yaitu Suryong, Partai Politik dan massa. Ideologi Juche tersebut berperan penting sebagai sarana pencuci otak dalam membentuk loyalitas dan dedikasi rakyat korea kepada pemimpin negara. Kondisi tersebut diperkuat oleh sistem pemerintahan autoritarian yang dilaksanakan pemerintah korea Utara. Akan tetapi perlu dipahami bahwa ideologi Juche ini hanya berlaku di Korea Utara dan tidak disebarkan ke negaranegara lain (Erik, 2005). Ideologi Juche sendiri bersifat fleksibel, dalam artian bahwa ideologi tersebut berlaku sesuai dengan kebutuhan dan perkembangan zaman. Untuk melihat bagaimana pola-pola dari ideologi juche yang sesuai dengan perkembangan zaman dapat dilihat dari tabel di bawah ini:

Tabel 1. Perubahan ideologi juche dan strategi politik internal Korea Utara

\begin{tabular}{ll}
\hline Tahun & Keterangan \\
Sebelum 1980 & $\begin{array}{l}\text { Ideology Juche (identitas Nasional, kemerdekaan, dan } \\
\text { perjuangan mandiri }\end{array}$ \\
$1980-1989$ & Aksi masa, Anti imperialisme, Solidaritas Internasional \\
$1989-1992$ & Superioritas sosialisme \\
$1990-2000$ & $\begin{array}{l}\text { Optimisme sosialisme ala Korea Utara, Loyalitas } \\
\text { terhadap pemimpin partai, Red Banner Ideology, Kangsung } \\
\text { Daeguk (negara kuat adalah negara yang memiliki militer } \\
\text { yang kuat dan kesejahteraan ekonomi) } \\
\text { Ideologi militer }\end{array}$ \\
&
\end{tabular}

Aspek lain yang berhubungan erat dengan rezim Kim Il Sung adalah pembangunan citra ketokohan dan kepahlawanan Kim Il Sung sebagai pembentuk rasa nasionalisme, fanatisme dan loyalitas masyarakat Korea Utara terhadap rezim komunis. 
DIAKRONIKA 20 (1) 2020

ISSN: 1411-1764 (Print) | 2620-9446 (Online)

Pembentukan sikap fanatisme dan loyalitas masyarakat Korea Utara dilaksanakan dengan mengunakan budaya dalam hal ini film-film dan slogan-slogan indoktrinasi kebesaran Korea Utara. Beberapa pertunjukan opera bertema sejarah yang dipergelarkan sekitar tahun 1970-an mengangkat alur cerita yang sama yaitu bagaimana kondisi masyarakat yang tertindak akibat pendudukan Jepang, kapitalisme dan Korea Selatan hingga akhirnya mereka menemukan jalan keluar berkat bimbingan dan petunjuk dari sang pemimpin.

"The audience followed wholeheartedly the switches of fate, cried uncontrollably when a landowner's wife threw boiling water over a servant's four-year-old daughter, blinding her, and cheered when Kim Il Sung's partisans justly punished the Japanese occupiers and their Korean upper-class collaborators. The music was somewhat special or, rather, it was not really special at all. It was not East Asian but clearly European, and if one was at all musical one could recognize many tunes from Western operas and operettas. The general impression was a mixture of Swan Lake and a romantic Viennese operetta. And the personality cult naturally was always present in the form of choruses or songs full of phrases such as 'the rich blossom of the magnolias expresses an endless and unlimited gratitude to the great Sun of the Fatherland', which, of course, referred to the Great Leader. On such occasions, the audience would rise up from their seats and loudly express their approval, clapping their hands above their heads. (Lankov, 2007)"

Selain pertunjukan oprea, musik juga menjadi bagian dari indoktrinasi dan propaganda. Salah satu musikalisasi terdapat dalam pertunjukan The Song of Paradise dan My Juche Country yang menggambarkan kegembiraan dan kesejahteraaan rakyat dibawah pimpinan Pemimpin Besar (Erik, 2005). Museum museum di Korea Utara seperti Museum Fatherland Liberation War di Pyongyang menggambarkan sentralitas peran Kim Il Sung. Perayaan-perayaan tahunan di Korea Utara juga mengambil tema yang sama yaitu ketokohan dan kepahlawanan Kim Il Sung sebagai pemimpin besar Korea Utara (Kim, 2010).

Sementara itu di ruang-ruang pendidikan masyarakat Korea Utara, ketokohan dan kepahlawanan Kim Il Sung juga nyata dapat dilihat. Sebagai contoh di rung Grand Poeple Study House yang merupakan pusat studi bagi masyarakat Korea Utara. Di GPSH terdapat bagitu banyak lukisan mengenai peristiwa penting dalam sejarah Korea Utara dimana kakak buyut dari Kim Il Sung yaitu Kim Ung U memimpin perlawanan dalam insiden dengan kapal Amerika (Adams, 2017; Burdick, 2014). Mata pelajaran 
Nur Fatah Abidin

Dinamika Politik, Heroifikasi Kim Il Sung, dan Ideologi Juche di Korea Utara (1948-2011)

sejarah berisi perjalanan hidup Kim Il Sung dan keluarganya. Pendidikan moral dan sosial diunduh dari masa kecil dari Kim Il Sung atau pada aktivitas Kim Il Sung selama revolusi (Ford \& Kwon, 2007). Bahkan dalam mata pelajaran Matematika, ketokohan dan kepahlawanan begitu tampak, yaitu sebagai berikut:

Three soldiers from Korean Poeple's Army killed 30 American

Soldiers, how many American soldiers were killed by each of them, if

they all killed equal of enemy soldiers? (Ford \& Kwon, 2007)

Bahkan komik pun juga digunakan sebagai sarana indoktrinasi. Komik di Korea Utara bersifat nasionalis dan kepahlawanan dengan tema anti-Amerika, anti-Jepang dan anti-Kapitalis. Komik di Korea Utara ditujukan untuk kamu remaja dan dewasa. Dialog dalam komik berkisar pada perasaan nasionalisme yang kuat dan pembentukan ideologi dengan alur cerita yang simple yaitu mengenai tentara ataupun anak-anak yang bersedia mati dengan pemimpin, masyarakat dan negara (Ford \& Kwon, 2007; Lee \& English, 2016). Dengan demikian pendidikan menduduki peran penting dalam masyarakat dan budaya. Pendidikan digunakan penguasa untuk meningkatkan dan menyebarkan pemikiran kolektif dan nasionalisme.

Meskipun Kim Il Sung telah tiada, kepahlawanan dan ketokohannya tetap berada dalam ingatan kolektif masyarakat Korea Utara. Keberadaannya dalam ingatan masa lalu, masa kini dan masa akan datang menunjukkan bahwa Kim Il Sung bukan hanya sekedar seorang pemimpin, tetapi sesorang yang benar-benar telah dikultuskan oleh masyarakat Korea Utara (Harrold, 2004). Hal tersebut diperkuat oleh reproduksi simbol-simbol kepahlawanan Kim Il Sung dalam kehidupan masyarakat Korea Utara. Reproduksi tersebut penting untuk menjaga nasionalisme, loyalitas dan fanatisme masyarakat Korea Utara terhadap rezim yang berkuasa. Wujud dari kesinambungan simbol-simbol kepahlawanan Kim Il Sung tampak pada pengkultusan genealogi keluarga yang melegitimasi kekuasaan keturunannya sampai dengan saat ini (Mastro, 2020).

\section{Politik Isolasi, Hukuman, dan Proses Suksesi}

Politik isolasi yang dilakukan oleh rezim Kim Il Sung digambarkan oleh Erik Cornell (2005), mantan duta besar Swedia di Korea Utara sebagai berikut:

"Pyongyang`s transport communications with the rest of the worl were restricted, to say the least: two train departures and two flights a week to and from Beijing, and one of each to and from Moscow. In addition, there were two flight a week between Pyongyang and Khabarovsk in eastern Siberia, where one could change to the Soviet Russian domestic network or fly to Nigata Japan." (Erik, 2005) 
DIAKRONIKA 20 (1) 2020

ISSN: 1411-1764 (Print) | 2620-9446 (Online)

Sebagai negara dengan kebijakan tertutup, masyarakat menganggap Korea Utara begitu tertutup dan tidak mengizinkan satupun warga negara asing, khususnya Amerika Serikat, untuk berkunjung ke Korea Utara. Meskipun demikian, pada masa kekinian, Korea Utara mulai membuka diri terhadap unsur-unsur dari luar. Korea Utara mulai intens dalam melakukan event-event bertaraf internasional serta mengundang wartawan dan aktivis asing ke dalam negeri mereka (Burdick, 2014). Namun, demikian, persepsi negatif terhadap Korea Utara tidak dapat begitu saja dihilangkan karena terkait permasalahan isu nuklir dan politik global, khusunya dalam konteks ketegangan antara Korea Utara dan Amerika Serikat (Chung, 2019; Scobell et al., 2019).

Pemerintah mengontrol media massa, internet, buku-buku asing dan majalah. Aktivitas berpergian membutuhkan izin perjalanan dengan izin bepergian ke luar negeri yang sangat terbatas. Buku asing tersedia di perpustakaan dan jumlahnya sangat terbatas. Akses untuk membaca buku-buku tersebut juga sangat dibatasi. Akses pada media dan penggunaan internet juga dibatasi, hanya buku-buku yang telah disensor yang beredar dalam masyarakat. Meskipun mobile phone telah diperkenalkan di Korea Utara pada bulan November 2002, tetapi semua mobile phone tersebut kemudian ditarik delapan belas bulan kemudian pada bulan Mei 2004. Hal tersebut dikarenakan isu penggunaan mobile phone dalam rencana pembunuhan Kim Jong Il dalam perjalanannya ke Beijing. Koran yang paling berpengaruh di Korea Utara adalah Rodong Sinmun yang merupakan salah satu organ dari Komite Sentral Partai Pekerja Korea. Editorial Rodong Sinmun merefleksikan pesan dari partai serta pemimpin Korea Utara. Tajuk-tajuk berita kora di dominasi berita kunjungan pemimpin, penghargaan ekonomi, kesuksesan olahraga dan lain sebagainya. Sementara itu dalam kolom berita luar negeri, pemberitaan mengenai Amerika Serikat dan Jepang diiringi dengan pemberitaan bahaya kapitalisme. Sebaliknya, pemberitaan mengenai China dan negara Eropa antiAmerika identik dengan kesuksesan ekonomi (Ford \& Kwon, 2007).

Sebagai suatu rezim yang terlihat kokoh, pelaksanaan pemerintahan dalam negeri Korea Utara juga mengalami ganjalan-ganjalan khususnya terkait eksistensi rezim Komunis Korea Utara. Dalam hal ini terjadi beberapa peristiwa percobaan pembunuhan serta hukuman-hukuman mati kepada rakyat Korea Utara, baik yang terekspos media massa ataupun tidak. Organ pemerintah yang digunakan untuk melaksakanan kebijakan represif adalah militer. Korea Utara menempati posisi keempat sebagai angkatan bersenjata dunia. Moral perang pasukan Korea Utara sangat tinggi karena indoktrinasi dan dedikasi mereka dalam pertahanan nasional. Budget militer pada tahun 1998 sebesar US \$2,400,000 sampai denhan 5,400,000,000. Dengan kekuatan militer tersebut rezim penguasa dapat menumpas gerakan oposan dengan efektif (Son, 2006). 
Percobaan kudeta yang paling besar dalam sejarah Korea Utara terjadi pada tahun 1956 ketika proyek de-stalinisasi merambah Korea Utara. Proyek tersebut telah mendorong kelompok pro USSR untuk melakukan reformasi di Korea Utara dengan desakan agar Kim Il Sung melepaskan jabatannya. Meskipun demikian, gerakan tersebut pada akhirnya dapat dipadamkan oleh rezim yang berkuasa. Sementara itu, salah satu percobaan pembunuhan yang diliput oleh media massa internasional terjadi ketika Kim Il Sung melakukan lawatan ke Korea Selatan pada tanggal 17 November 1986. Agaknya percobaan-percobaan pembunuhan juga tetap terjadi meskipun dalam skala kecil ataupun besar (Sigal, 1999).

Dalam menghadapi gerakan-gerakan pembelot tersebut, rezim Korea Utara memang melaksanakan kebijakan represif dengan melakukan teror terhadap gerakangerakan oposisi. Teror tersebut diwujudkan dalam bentuk hukuman mati bagi siapa saja yang terindikasi menentang pemerintahan ataupun disinyalir dapat menyebabkan gejolak dalam negeri. Bentuk-bentuk teror hukuman mati melalui ditembak, dibakar, ditembak mortir, diracun. Bahkan hukuman mati dapat dikenai kepada siapapun termasuk kerabat ataupun pejabat tinggi. Bahkan insiden yang cukup menggelitik adalah ketika Hyon Yong Choi dijatuhi hukuman mati karena tertidur dalam sebuah acara resmi yang dihadiri Kim Jong Un. Meskipun demikian tidak ada catatan pasti berapa jumlah kaum oposan yang dihukum mati. Akan tetapi, khusus pada masa pemerintahan Kim Jong Un saat ini, pemberitaan media massa mulai mengekspos hukuman tersebut. Pemberitaan paling fenomenal mengenai hukuman mati terkait eksekusi paman Kim Jong Un yaitu Jang Song Taek yang dihukum pada Desember 2013. Dengan demikian dapat disimpulkan bahwa hukuman mati merupakan bentuk teror terhadap lawan politik penguasa Korea Utara. Dengan demikian, hukuman mati tersebut memiliki dua fungsi: (1) sebagai cara penumpasan efektif gerakan-gerakan oposan dan (2) intimidasi dan teror terhadap lawan politik penguasa.

Proses suksesi kekuasaan dan kepemimpinan di Korea Utara agaknya memiliki pola yang hampir sama dalam setiap generasi, dimana kekuasaan dari ayah diwariskan kepada anaknya. Pemilihan pewaris kekuasaan merupakan hak prerogratif ayah. Meskipun bersifat nepotis, mekanisme pemilihan tetap melalui saluran-saluran bersifat demokratis yaitu Partai Pekerja Korea Utara. Dengan demikian proses suksesi mendapatkan legitimasi setidaknya dari dua sisi, yaitu genealogi dan politis. Mekanisme suksesi kekuasaan dapat dilihat pada tahun 1994, ketika Kim Il Sung menginggal dunia. Kim Jong Il ditetapkan sebagai pengganti Kim Il Sung. Karir politik Kim Jong Il dimulai pasca menyelesaikan sekolah di Universitas Kim Il Sung, Kim Jong Il kemudian ditempatkan di Departemen Organisasi Partai Pekerja Korea. Posisinya semakin meningkat tatkala ditunjuk sebagai wakil dalam Komite Politburo pada tahun 1980 (Oh \& Hassig, 2004). 
DIAKRONIKA 20 (1) 2020

ISSN: 1411-1764 (Print) | 2620-9446 (Online)

Kim Jong Il mulai membangun dukungan dan kekuatan ketika ditunjuk sebagai wakil presiden dari Komisi Pertahanan Nasional pada bulan Mei 1990 dan kemudian diangkat sebagai pemimpin besar Angkatan Perang Rakyat Korea pada 1991. Meskipun Kim Jong Il tidak pernah mengenyam pendidikan militer. Dalam kesempatan tersebut Kim Jong Il melakukan langkah luar biasa dengan mengganti lebih dari 1000 jenderal dan staf senior dengan generasi muda yang loyal kepadanya (Buzo, 2018; Lim, 2008). Pola yang sama terjadi pada tahun 2007 ketika Kim Jong Il mengalami penurunan kesehatan dan mulai memilih pewaris kekuasaan. Spekulasi mulai berkembang bahwa Jang Song Taek (berumur 61 tahun pada tahun 2007) akan menjadi suksesor Kim Jong Il akan tetapi perbedaan agenda reformasi dengan Kim Jong Il telah menurunkan kesempatannya. Putra tertua Kim Jong Il, Kim Jong Nam, juga jauh dari pilihan ayahnya. Spekulasi kemudian berganti kepada dua orang anak Kim Jong Il, yaitu Kim Hong Chol dan Kim Jong Un yang masih berusia sekitar dua puluh tahun pada 2007. Kim Jong Chol terdepak dari bursa kepemimpinan pasca insiden kepergiannya ke Disney Land pada tahun 2001. Pasca insiden tersebut, peluang Kim Jong Un untuk menggantikan Kim Jong Il semakin besar. Terbukti pada 2011, tahun kematian Kim Jong Il, Kim Jong Un kemudian diangkat sebagai pengganti Kim Jong Il pada tahun 2011.

\section{Simpulan}

Kebijakan dalam negeri yang berhubungan dengan bagaimana rezim komunis menekan dan menghapuskan segala ancaman dari kaum oposan yang ingin menjatuhkan mereka. Bentuk-bentuk strategi yang dilakukan adalah dapat dikategorikan ke dalam tiga strategi. Pertama, penyusunan strategi preventif dan represif seperti ideologi negara yaitu Juche ideologi yang merupakan akulturasi dari semangat komunis dan budaya setempat dan politik isolasi. Kedua, Memperkuat birokrasi dan militer yang loyal terhadap penguasa. Dengan alat birokrasi dan militer tersebut penguasa, khususnya pemimpin utama Korea Utara dapat dengan mudah mengamankan kekuasaannya. Penggunaan teror sebagai bentuk langkah represi terhadap para oposan. Teror dapat dilakukan dengan penggunaan hukuman mati bagi siapa saja yang melakukan kesalahan, baik besar ataupun kecil. Penguasa utama, dalam hal ini keluarga Kim Il Sung dapat menggunakan alat teror ini sebagai usaha meminimalisir gerakan oposan dari dalam negeri. Keterbatasan dari penelitian ini adalah penggunaan literature pustaka sekunder untuk mendeskripsikan kebijakan politik dalam negeri Korea Utara. Tentunya, penggunaan sumber sekunder ini memiliki beberapa kelemahaman metodologis dan validitas data. Penyusunan sumber sejarah Korea Utara idealnya ditulis berdasakan sumber primer dan perspektif masyarakat 
Nur Fatah Abidin

Dinamika Politik, Heroifikasi Kim Il Sung, dan Ideologi Juche di Korea Utara (1948-2011)

Korea Utara sendiri untuk meminimalisir prasangka dan stigmatisasi. Meskipun demikian, penelitian ini dapat menjadi landasan awal untuk mengetahui dinamika politik internal dan kebijakan politik luar negeri Korea Utara. Setidaknya melalui kajian ini, masyarakat Indonesia dapat lebih bijak dalam menanggapi dinamika politik global kontemporer, khusunya jika terkait dengan permasalahan Korea Utara.

\section{Daftar Rujukan}

Adams, J. (2017). English education in North Korea in the 1990s-2000s: the perspectives of two defectors. In Korean Englishes in Transnational Contexts (pp. 221-237). Springer.

Burdick, E. (2014). Three Days in the Hermit Kingdom: An American Visits North Korea. McFarland.

Buzo, A. (2018). The Guerilla Dynasty: Politics and Leadership in North Korea. Routledge.

Choi, E. K., Kim, E. H., \& Merrill, Y. (2003). North Korea in the world economy. Routledge.

Choi, S. (2014). Re-Imagining North Korea in International Politics: Problems and Alternatives. Routledge.

Chung, K. Y. (2019). Media as soft power: the role of the South Korean media in North Korea. The Journal of International Communication, 25(1), 137-157.

Erik, C. (2005). North Korea under communism: report of an envoy to paradise. Routledge.

Ford, G., \& Kwon, S. (2007). North Korea on the brink: struggle for survival. Pluto Press.

Harrold, M. (2004). Comrades and Strangers: Behind the Closed Doors of North Korea. John Wiley \& Sons.

Kim, S.-Y. (2010). Illusive utopia: theater, film, and everyday performance in North Korea. University of Michigan Press.

Lankov, A. (2007). Crisis in North Korea: The Failure of De-Stalinization, 1956. University of Hawaii Press.

Lee, A. R., \& English, D. A. (2016). Human rights violations in the North Korean education system: Voices of North Korean refugees in South Korea. SNU Journal of Education Research.

Lim, J.-C. (2008). Kim Jong-il's Leadership of North Korea. Routledge.

Lutz, T. (2015). Cult of Personality: North Korea under Kim Il-Sung.

Mason, R. (2020). The Korean War and US-Indonesia Relations, 1950-1954. Journal of International Studies, 11, 49-64.

Mastro, O. S. (2020). All in the Family: North Korea and the Fate of Hereditary Autocratic Regimes. Survival, 62(2), 103-124.

Mobrand, E., \& Kim, H. (2019). Southeast Asia's Roles in Inter-Korean Affairs. East Asian Policy, 11(03), 50-58.

O Hanlon, M., \& Mochizuki, M. (2004). Crisis on the Korean Peninsula: How to Deal with a Nuclear North Korea. KOREA OBSERVER, 35(1), 165-168.

Oh, K., \& Hassig, R. C. (2004). North Korea through the looking glass. Brookings Institution 
DIAKRONIKA 20 (1) 2020

ISSN: 1411-1764 (Print) | 2620-9446 (Online)

Press.

Pardo, R. P. (2019). North Korea-US Relations: From Kim Jong Il to Kim Jong Un. Routledge.

Pollack, J. D. (2017). No exit: North Korea, nuclear weapons, and international security. Routledge.

Scobell, A., Beauchamp-Mustafaga, N., Cevallos, A., Chan, A., \& Winkelman, Z. (2019). Netizen Opinion and China's Foreign Policy: Interpreting Narratives about North Korea on Chinese Social Media. Asia Policy, 26(3), 97-122.

Sigal, L. V. (1999). Disarming strangers: nuclear diplomacy with North Korea (Vol. 81). Princeton University Press.

So, W., \& Duarte, F. (2020). Cartographers of North Korea: Who are they and what are the technical, political, and social issues involved in mapping North Korea. Geoforum, 110, 147-156.

Son, K. (2006). South Korean engagement policies and North Korea: identities, norms and the sunshine policy. Routledge.

Winstanley-Chesters, R. (2020). Fishing in North Korea, A History and A Geography. In Fish, Fishing and Community in North Korea and Neighbours (pp. 99-134). Springer.

Zed, M. (2004). Metode peneletian kepustakaan. Yayasan Obor Indonesia. 